\title{
The effect of environmental conditions on the distribution of eggs and larvae of anchovy (Engraulis encrasicolus L.) in the Black Sea
}

\author{
Ahmet E. Kideys, Anna D. Gordina, Ferit Bingel, and \\ Ulrich Niermann
}

Kideys, A. E., Gordina, A. D., Bingel, F., and Niermann, U. 1999. The effect of environmental conditions on the distribution of eggs and larvae of anchovy (Engraulis encrasicolus L.) in the Black Sea. - ICES Journal of Marine Science, 56 Supplement: $58-64$.

Recent events in the Black Sea have had a severe impact on all compartments of the ecosystem, including ichthyoplankton. The distribution of eggs and larvae of the anchovy, the major commercial fish species, was investigated in relation to ambient conditions in the southern Black Sea during July 1992, August 1993, and June-July 1996. Average highest egg and larva numbers were observed in June-July 1996. Ichthyoplankton distribution was closely connected with the hydrography. Besides surface temperature and salinity, among the numerous biotic parameters tested, abundance of fodder zooplankton and of the ctenophore Mnemiopsis leidyi showed significant correlations with the distribution of either eggs or larvae of the anchovy. The results help in explaining the shift observed in the spawning grounds.

(C) 1999 International Council for the Exploration of the Sea

Key words: Black Sea, anchovy, ichthyoplankton, distribution.

A. E. Kideys, F. Bingel, U. Niermann: Institute of Marine Sciences, P.O. Box 28, Erdemli, 33731 Turkey; A. D. Gordina: Institute of Biology of the Southern Seas, Ukranian Academy of Science, Nachimov Ave. 2, Sevastopol, Ukraine.

\section{Introduction}

Analysis of catch data of the anchovy (Engraulis encrasicolus $\mathrm{L}$.) discloses interesting events taking place in the Black Sea ecosystem. Since the late 1960s, the Turkish catch of this most abundant fish species of the Black Sea has increased gradually to approximately $500000 \mathrm{t}$ in 1989 (Fig. 1). The increase is due to new technology in fishing, but also to factors such as the beneficial effects of increased nutrients, particularly on the north-western shelf (Zaitsev, 1992). In addition, predator pressure appears to have decreased. Moreover, the coupling between the benthic and pelagic sub-systems was disturbed owing to mass mortalities of benthic filterfeeders, which may have left a larger proportion of the production available for pelagic fish. Kovalev et al. (1998) suggested that increasing nutrient input via major rivers was responsible for the significant increase in both phytoplankton and edible zooplankton biomass (excluding gelatinous species), particularly in the deep waters of the eastern Black Sea. The increase in zooplankton, which is the main food for anchovy, could have had a

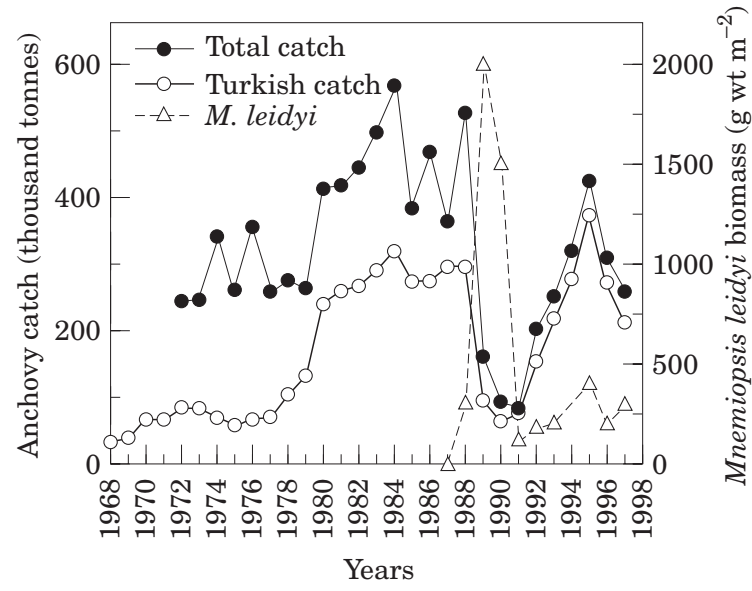

Figure 1. Time series of anchovy catch from the Black Sea and biomass of Mnemiopsis leidyi (Turkish catch data from DIE, 1968-1997; total anchovy catch from FAO; M. leidyi data for 1991-1993 from Mutlu et al., 1994). 

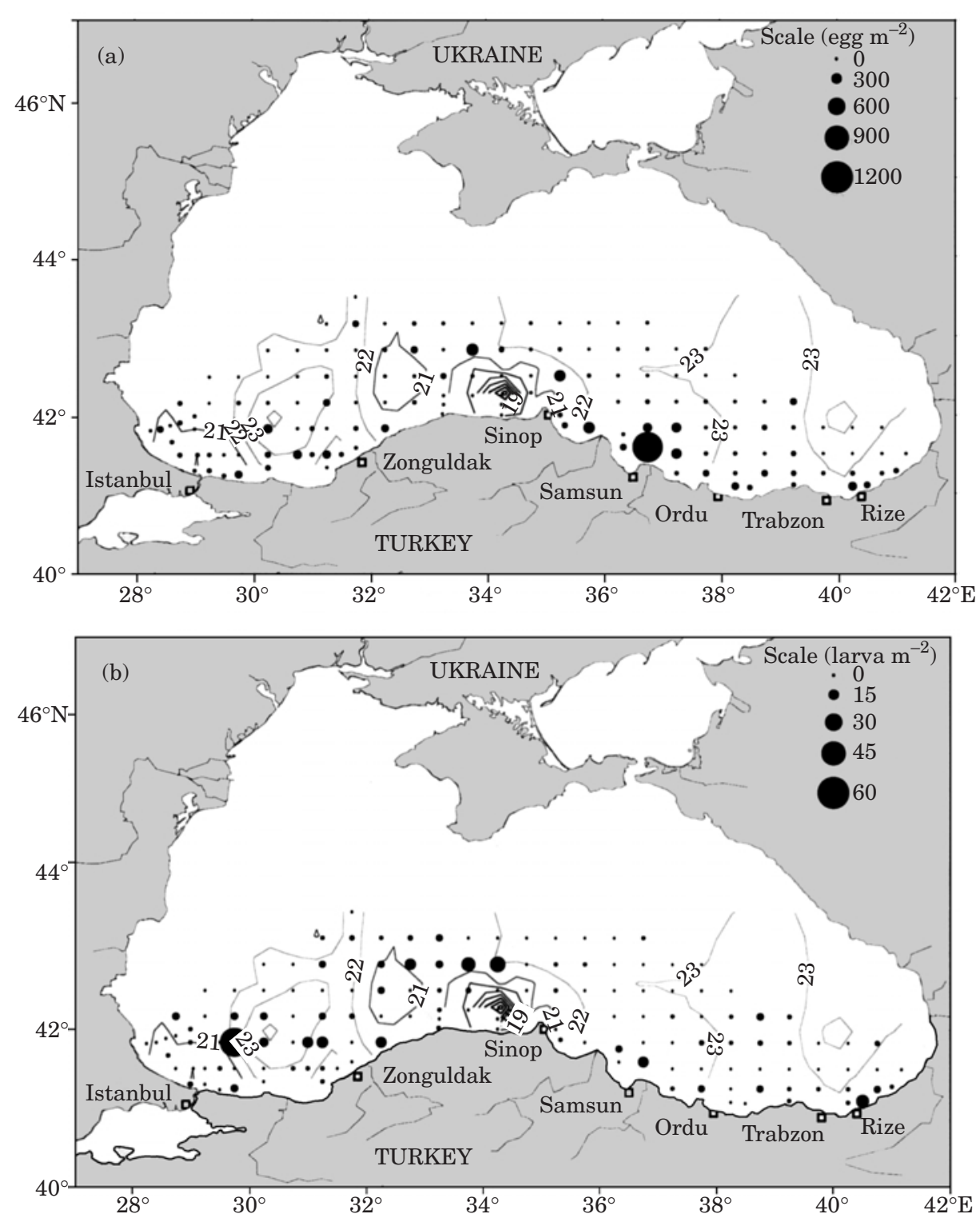

Figure 2. Distribution of $[\mathrm{A}]$ anchovy eggs and [B] larvae in the southern Black Sea during the July 1992 survey $\left(\mathrm{N} \mathrm{m}^{-2}\right)$. Surface isotherms $\left({ }^{\circ} \mathrm{C}\right.$ at $5 \mathrm{~m}$ ) are also shown (modified from Niermann et al., 1994).

positive effect on the population size of this species. However, eutrophication (particularly in the shallow north-western region) in combination with overfishing and the recent appearance of the competing invader Mnemiopsis leidyi (Ctenophora) appears to have caused an abrupt decrease to $60000 \mathrm{t}$ in the anchovy catch by the end of the 1980s (Kideys, 1994; Fig. 1). After the sudden decline, the catch has again consistently increased to a maximum of $374000 \mathrm{t}$ in 1995.

Striking changes have also been observed in the reproductive strategy of anchovy, as may be inferred from the long-term distribution of the early life stages. In contrast to earlier studies, numbers of eggs in the south-eastern Black Sea in particular in recent years are higher than in the north-western region (Niermann et al., 1994), which was formerly known as the main spawning area (Ivanov and Beverton, 1985). Recent studies confirm that the main spawning areas have now been established along the Turkish coast (Kideys et al., 1998). However, the distribution of eggs and larvae in the southern Black Sea is not uniform and the environmental factors responsible for the heterogeneity are not 

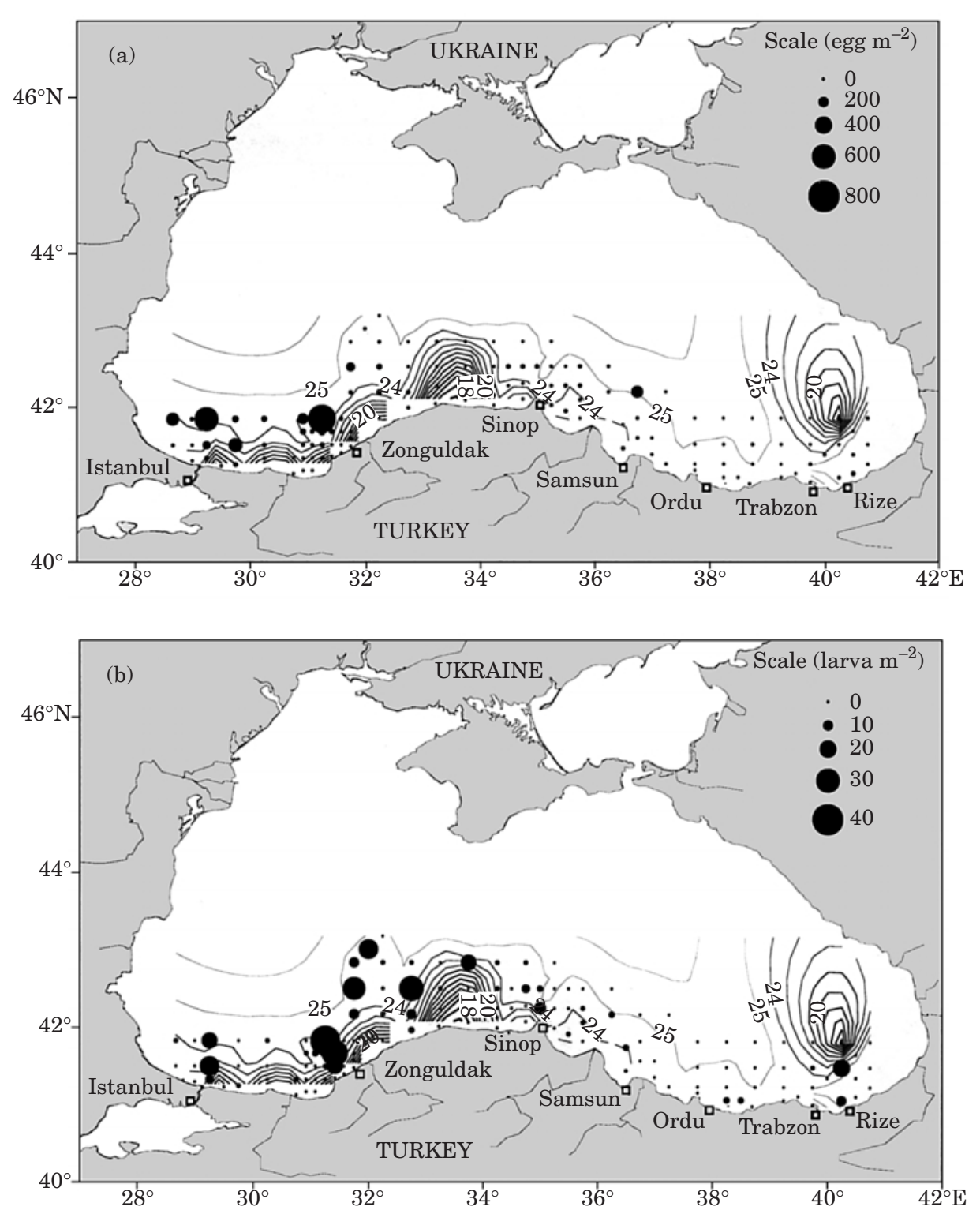

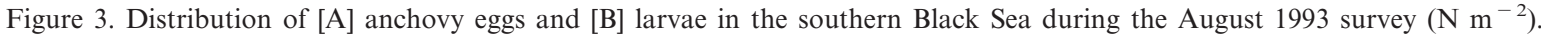
Surface isotherms $\left({ }^{\circ} \mathrm{C}\right.$ at $\left.5 \mathrm{~m}\right)$ are also shown.

known. We investigate the effect that some environmental factors may have had on the distribution of anchovy eggs and larvae.

\section{Materials and methods}

During surveys in 1992 (3-26 July; 144 stations), 1993 (4-22 August; 143 stations), and 1996 (20 June-6 July; 120 stations) on board the RV "Bilim", ichthyoplankton was collected from a dense station grid in the Turkish Exclusive Economic Zone covering the entire southern Black Sea. All samples were obtained via vertical tows (towing speed approximately $0.5 \mathrm{~m} \mathrm{sec}^{-1}$ from the anoxic zone to the surface using a Hensen net $(300 \mu \mathrm{m}$ mesh size and a net opening of $70 \mathrm{~cm}$ diameter). The depth of the lower boundary of the oxic zone varies spatially in the Black Sea, but is consistent with a density of $\sigma_{t}=16.2$. The appropriate sampling depth was thus derived from density measurements. Bucket contents were filtered using a 2-mm sieve to retain gelatinous organisms, which were quantified only during the July 1996 survey. The volume of each ctenophore (Mnemiopsis leidyi) was measured, while diameter was measured for individual ctenophores (Pleurobrachia 

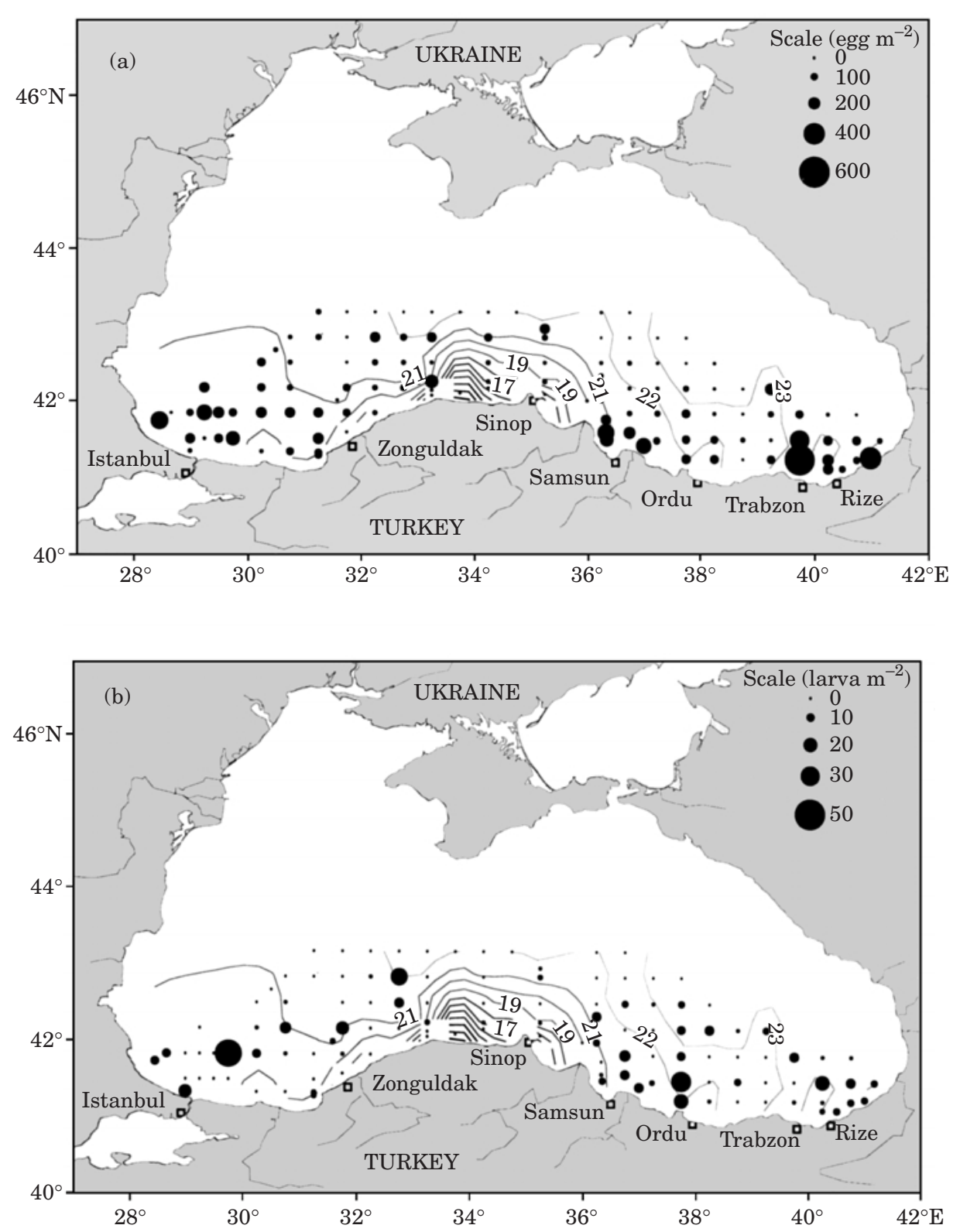

Figure 4. Distribution of [A] anchovy eggs and [B] larvae in the southern Black Sea during the June-July 1996 survey $\left(\mathrm{N} \mathrm{m}^{-2}\right)$. Surface isotherms $\left({ }^{\circ} \mathrm{C}\right.$ at $5 \mathrm{~m}$ ) are also shown.

pileus) and cnidarians (Aurelia aurita). The filtrates were fixed with buffered formalin (final concentration of $4 \%$ ) for sorting in the laboratory under a binocular microscope.

With the exception of the July 1992 cruise, all zooplankton organisms (mainly copepods) were staged and counted along with the ichthyoplankton. Biomass values were calculated using existing conversion values (Petipa, 1957). Temperature, salinity, and density of the water column were measured using a CTD probe at each station until the depth at which $\sigma_{\mathrm{t}}=16.2$. All tests were performed using the Spearman Rank correlation (Zar, 1984).

\section{Results and discussion}

Distributions of eggs and larvae of the anchovy as well as the surface temperatures are shown in Figures 2, 3 , and 4 for the surveys in 1992, 1993, and 1996, 
Table 1. Densities of anchovy eggs and larvae in the southern Black Sea, 1957-1996.

\begin{tabular}{|c|c|c|c|c|c|c|}
\hline \multirow[b]{2}{*}{ Year } & \multirow[b]{2}{*}{ Month } & \multicolumn{2}{|c|}{$\operatorname{Egg}\left(\mathrm{N} \mathrm{m}^{-2}\right)$} & \multicolumn{2}{|c|}{$\operatorname{Larva}\left(\mathrm{N} \mathrm{m}^{-2}\right)$} & \multirow[b]{2}{*}{ Reference } \\
\hline & & Range & Mean & Range & Mean & \\
\hline 1957 & July & $0-321$ & $\simeq 18$ & & $\simeq 2$ & (1) \\
\hline 1991 & June & $0-29$ & $\simeq 6$ & $0-2$ & $\ll 1$ & (2) \\
\hline 1992 & July & $0-1167$ & 72 & $0-55$ & 3.5 & (3) \\
\hline 1993 & August & $0-718$ & 39 & $0-39$ & 3.1 & (3) \\
\hline 1996 & June-July & $0-577$ & 90 & $0-44$ & 4.3 & (3) \\
\hline
\end{tabular}

References: (1) Einarsson and Gurturk, 1960, (2) Niermann et al., 1994, (3) This study.

Table 2. Spearman's rank correlation analyses between biotic and abiotic factors by survey (bold numbers are significant; - indicates inverse relationship; E: eggs; L: larvae; T: temperature; S: salinity; $\mathrm{N}$ : Noctiluca biomass; Zb: zooplankton biomass; Za: zooplankton abundance; Ma: Mnemiopsis abundance; Mb: Mnemiopsis biomass).

\begin{tabular}{|c|c|c|c|c|c|c|c|c|}
\hline a. June-July 1996 & $\mathrm{~L}$ & $\mathrm{~T}$ & $\mathrm{~S}$ & $\mathrm{Nb}$ & $\mathrm{Zb}$ & $\mathrm{Za}$ & Ma & $\mathrm{Mb}$ \\
\hline E & $<0.01$ & -0.83 & $-<0.01$ & 0.11 & 0.95 & $<0.01$ & $<0.01$ & $<0.01$ \\
\hline $\mathrm{L}$ & & $<0.01$ & -0.72 & 0.48 & -0.20 & 0.73 & 0.11 & 0.09 \\
\hline $\mathrm{T}$ & & & -0.10 & $-<0.01$ & 0.32 & $-<0.01$ & $-<0.05$ & -0.19 \\
\hline $\mathrm{S}$ & & & & 0.62 & 0.51 & 0.65 & $-<0.01$ & $-<0.01$ \\
\hline $\mathrm{Nb}$ & & & & & $-<0.01$ & 0.80 & 0.06 & 0.14 \\
\hline $\mathrm{Zb}$ & & & & & & $<0.01$ & 0.73 & 0.60 \\
\hline $\mathrm{Za}$ & & & & & & & $<0.05$ & $<0.05$ \\
\hline $\mathrm{Ma}$ & & & & & & & & $<0.01$ \\
\hline b. August 1993 & $\mathrm{~L}$ & $\mathrm{~T}$ & $\mathrm{~S}$ & $\mathrm{Za}$ & & & & \\
\hline $\mathrm{E}$ & $<0.01$ & 0.25 & 0.19 & 0.61 & & & & \\
\hline $\mathrm{L}$ & & 0.90 & 0.93 & 0.36 & & & & \\
\hline $\mathrm{T}$ & & & $-<0.01$ & -0.58 & & & & \\
\hline $\mathrm{S}$ & & & & -0.25 & & & & \\
\hline c: July 1992 & $\mathrm{~L}$ & $\mathrm{~T}$ & S & & & & & \\
\hline $\mathrm{E}$ & $<0.01$ & $<0.01$ & $-<0.01$ & & & & & \\
\hline $\mathrm{L}$ & & 0.22 & 0.55 & & & & & \\
\hline $\mathrm{T}$ & & & $<0.01$ & & & & & \\
\hline
\end{tabular}

respectively, and summaries of the ranges observed and means are given in Table 1. Although the maximum concentrations were obtained in 1992, the mean values for both eggs and larvae were highest in 1996. The numbers of eggs do not reflect the gradual increase in catch values (Fig. 1), but they were probably underestimated in 1993, when sampling was performed towards the end of the spawning season in August. Taking this imperfection into account, the data do suggest that the numbers of eggs and larvae have increased in recent years compared with the 1957 and 1991 values (Table 1). In 1957, the Black Sea was still in an oligotrophic state and, therefore, it could probably sustain only a relatively small pelagic fish stock. In 1991, the lowest numbers of eggs and larvae were observed, which coincides with the period when anchovy catches plummeted to their lowest value. The increase in eggs and larvae by 1996 might be taken as an indication of the recovery of the heavily disturbed Black Sea ecosystem.
During August 1993, the highest egg abundances were limited to the western part (in front of the Bosphorus and off Eregli). Besides the western region, two coastal areas in the eastern Black Sea were the most abundant localities in June-July 1996 (off Samsun and between Trabzon and Rize). The distribution pattern in the 1996 survey was similar but not as uniform as in the July 1992 survey.

The temperature distribution (at $5 \mathrm{~m}$ ) in the surveys differed notably. During August 1993, the temperature (maximum $28.8^{\circ} \mathrm{C}$, average $23.1^{\circ} \mathrm{C}$ ) was a few degrees higher than during the June-July 1996 survey (maximum $24.9^{\circ} \mathrm{C}$, average $21.4^{\circ} \mathrm{C}$ ). In 1993 in the western Black Sea there was a frontal current system along the coast, resulting in a sharp gradient. Highest egg and larval densities were observed at the warmer edge of this frontal system. Interestingly, the main downwelling area of the Black Sea, the Batumi Gyre (Oguz et al., 1993) was an upwelling area during this period. 


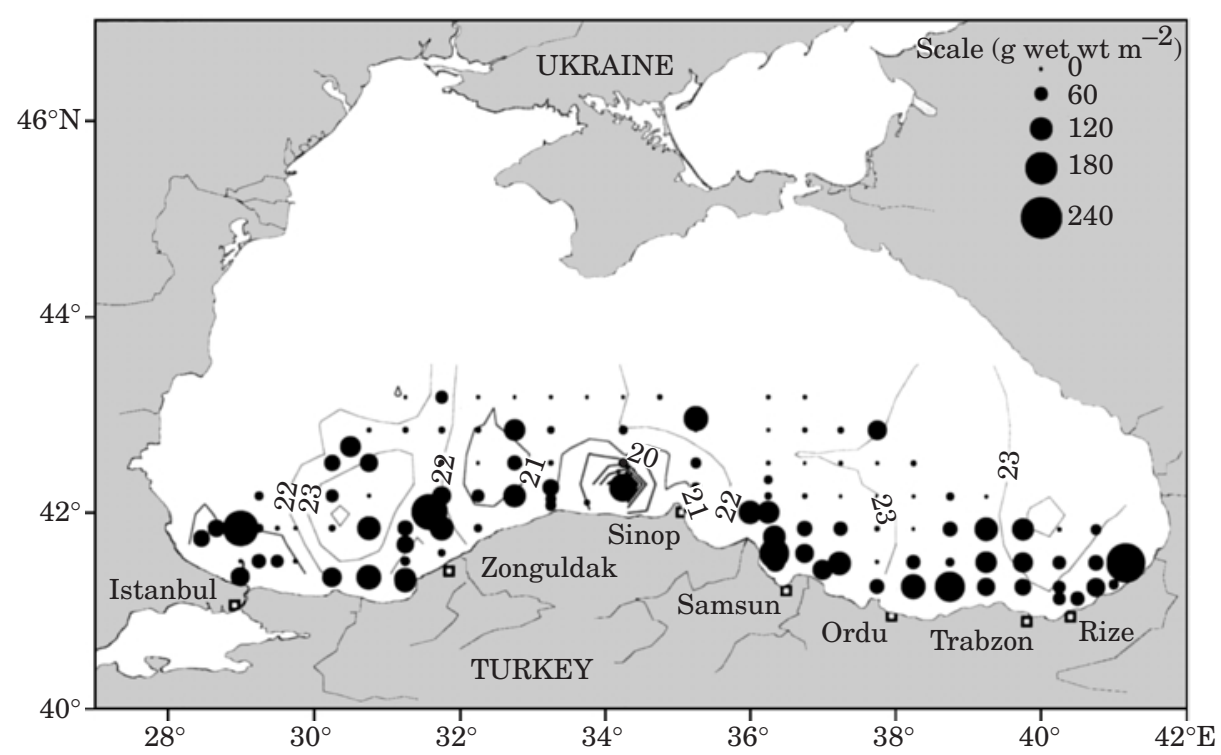

Figure 5. Distribution of Mnemiopsis leidyi biomass ( $\mathrm{g}$ wet weight $\mathrm{m}^{-2}$ ) in the southern Black Sea during the June-July 1996 survey. Surface isotherms $\left({ }^{\circ} \mathrm{C}\right.$ at $\left.5 \mathrm{~m}\right)$ are also shown.

During the 1996 survey, the only sharp gradient in surface temperature distribution was observed between Zonguldak and Sinop, with temperatures down to $17^{\circ} \mathrm{C}$ in the core. Upwelling in this region appears to be a consistent hydrographical feature during July, as it was also present during the 1957 and 1992 egg surveys (Einarsson and Gurturk, 1960; Niermann et al., 1994). Eggs and larvae were either absent or present in very low numbers in this region. This is not unexpected, because the presence of temperatures higher than $20^{\circ} \mathrm{C}$ is a prerequisite for maximum spawning of anchovy (Dekhnik, 1973; Demir, 1959). Niermann et al. (1994) found correspondingly very low egg numbers overall (without any larvae) in June 1991, when surface temperatures were below $20^{\circ} \mathrm{C}$, which is unusual for this month. In contrast, they found plenty of eggs and larvae during the July 1992 survey, with highest densities in the eastern region, which was warmer than the western region. We tested the effect of temperature on egg distribution and found a highly significant correlation for the 1992 survey but not for the 1993 and 1996 surveys (Table 2). For larvae, only the 1996 survey yielded a significant correlation with temperature. Since August is towards the end of the spawning season, the effect of temperature may not be clear at that time. Nevertheless, the lack of a correlation between temperature and egg numbers in the June-July 1996 survey suggests that other factors are also important.

According to Spearman's rank correlation analysis, salinity is another physical factor significantly affecting the distribution of anchovy eggs during both July 1992 and June-July 1996, but not during August 1993
(Table 2). The negative correlation implies that, besides the area in front of the Bosphorus affected by the Danube (Sur et al., 1994), the eastern Turkish coastal areas, which receive a high freshwater supply, should be suitable spawning grounds for anchovy.

The total number of edible zooplankton organisms (excluding gelatinous organisms and the heterotrophic dinoflagellate Noctiluca miliaris) also had a highly significant and positive effect on the distribution of anchovy eggs in the 1996 survey, for which extensive plankton data were available. Since anchovy continues feeding during spawning (Dekhnik 1954, cited in Einarsson and Gurturk, 1960), a high abundance of suitable zooplankton prey may enhance spawning concentrations. Similar correlations between the numbers of anchovy eggs and larvae and zooplankton biomass have been noted for Bulgarian waters by Zaika (1968).

Long-term biomass of edible zooplankton on the north-western shelf shows a decreasing trend in recent years, while the southern regions show an increasing trend (Kovalev et al., 1998). The same trends apply to phytoplankton. These changes in plankton biomasses should play a role in the observed shift in main spawning areas of anchovy from the north-western to the south-eastern Black Sea.

In all surveys, numbers of eggs and larvae showed extremely high correlations $(\mathrm{p}<0.0001)$. This is expected since the development time of an anchovy egg is as short as $24 \mathrm{~h}$, and therefore co-occurrence during sampling is inevitable. However, the high correlations also suggest that the main physical forces acting upon the two life 
stages are the same. This may partly explain why both abundance and biomass (Fig. 5) of Mnemiopsis also showed very high correlations $(\mathrm{p}<0.0007)$ with egg numbers in 1996.

Abundance and biomass of Mnemiopsis were also correlated significantly with the abundance of edible zooplankton in the water column $(\mathrm{p}<0.04)$. Thus, both Mnemiopsis and spawning anchovy, two competing species for food, appear to concentrate in areas where prey abundance is high, even though the competition is disadvantageous for the anchovy, as its eggs and larvae are also consumed by Mnemiopsis.

Of the biotic parameters checked (Table 2), only those discussed yielded significant correlations with anchovy eggs and larvae. However, interactions between significant and insignificant parameters, as well as others which have not yet been tested, might influence the distribution of anchovy eggs and larvae. For example, the heterotrophic dinoflagellate Noctiluca miliaris competes for food with copepods (Elbrachter and Qi, 1998) and a sudden increase in biomass of the former may cause a decrease in zooplankton biomass. Similarly, quality and quantity of phytoplankton may affect zooplankton composition and thus egg and larval distributions. The factors governing the distribution of planktonic organisms remain intricately interwoven in any ecosystem, as is seen in the Black Sea.

\section{Acknowledgements}

This work was supported by the Turkish Scientific and Technical Research Council (TUBITAK) and by a Linkage Grant (ENVIR.LG.974491) from NATO. We thank the crew of RV "Bilim" and Ethem Dipli for assistance at sea, and Alison Kideys and Dr Niels Daan for correcting the English.

\section{References}

Dekhnik, T. V. 1973. Ichthyoplankton of the Black Sea Naukova dumka, Kiev. 235 pp. (In Russian.)

Demir, N. 1959. Notes on the variations of eggs of anchovy (Engraulis encrasicolus Cuv.) from the Black Sea Marmara, Aegean and Mediterranean Seas. Publications of the Hydrobiological Research Institute, Faculty of Sciences, University of Istanbul, Series B: 180-187.

DIE 1968-1997. Fishery statistics. State Institute of Statistics, Printing Division, Ankara, Turkey.

Einarsson, H., and Gurturk, N. 1960. Abundance and distribution of eggs and larvae of anchovy (Engraulis encrasicolus Cuv.) in the Black Sea. Publications of the Hydrobiological
Research Institute, Faculty of Sciences, University of Istanbul, Series B: 71-94.

Elbrachter, M., and Qi, Y. Z. 1998. Aspects of Noctiluca (Dinophyceae) population dynamics. In Physiological Ecology of Harmful Algal Blooms, pp. 315-335. Ed. by D. M. Anderson, A. D. Cembella, and G. M. Hallegraeff. NATO ASI Series, Vol. G41. Springer-Verlag, Berlin.

Ivanov, L., and Beverton, R. J. H. 1985. The fisheries resources of the Mediterranean. Part two: The Black Sea. Studies and Reviews, General Fisheries Council for the Mediterranean, 60. $135 \mathrm{pp}$

Kideys, A. E. 1994. Recent dramatic changes in the Black Sea ecosystem: the reason for the sharp decline in Turkish anchovy fisheries. Journal of Marine Systems, 5: 171-181.

Kideys, A. E., Gordina, A. E., Niermann, U., Uysal, Z., Shiganova, T. A., and Bingel, F. 1998. Distribution of eggs and larvae of anchovy with respect to ambient conditions in the southern Black Sea during 1993 and 1996. In NATO TU-Black Sea Project: Ecosystem Modeling as a Management Tool for the Black Sea, Symposium on Scientific Results, pp. 189-198. Ed. by L. Ivanov, and T. Oguz. Kluwer Academic Publishers, Amsterdam.

Kovalev, A. V., Niermann, U., Melnikov, V. V., Belokopitov, V., Uysal, Z., Kideys, A. E., Unsal, M., and Altukhov, D 1998. Long-term changes in the Black Sea zooplankton: the role of natural and anthropogenic factors. In NATO TU-Black Sea Project: Ecosystem Modeling as a Management Tool for the Black Sea, Symposium on Scientific Results, pp. 221-234. Ed. by L. Ivanov, and T. Oguz. Kluwer Academic Publishers, Amsterdam.

Mutlu, E., Bingel, F., Gucu, A. C., Melnikov, V. V., Niermann, U., Ostr, N. A., and Zaika, V. E. 1994. Distribution of the new invader Mnemiopsis sp. and the resident Aurelia aurita and Pleurobrachia pileus populations in the Black Sea in the years 1991-1993. ICES Journal of Marine Science, 51: 407422.

Niermann, U., Bingel, F., Gorban, A., Gordina, A. D., Gücü, A. C., Kideys, A. E., Konsulov, A., Radu, G., Subbotin, A. A., and Zaika, V. E. 1994. Distribution of anchovy eggs and larvae (Engraulis encrasicolus Cuv.) in the Black Sea in 1991-1992. ICES Journal of Marine Science, 51: 395-406.

Oguz, T., Latun, V. S., Latif, M. A., Vladimirov, V. V., Sur, H. I., Markov, A. A., Ozsoy, E., Kotovshchikov, B. B., Eremeev, V. V., and Unluata, U. 1993. Circulation in the surface and intermediate layers of the Black Sea. Deep-Sea Research, 40: 1597-1612.

Petipa, T. S. 1957. On the mean weight of main forms of Black Sea zooplankton. Proceedings of Sevastopol Biol Stat, 9: 33-57 (In Russian.)

Sur, H. I., Ozsoy, E., and Unluata, U. 1994. Boundary current instabilities, upwelling, shelf mixing and eutrophication processes in the Black Sea. Progressive Oceanography, 33: 249-302.

Zaika, V. E. 1968. Some quantitative relationships between the biomass of the zooplankton and the anchovy (Engraulis encrasicholus ponticus Alex.). Proceedings of the Research Institute of Fisheries and Oceanography, Varna, 9: 17-29.

Zaitsev, Yu. P. 1992. Recent changes in the trophic structure of the Black Sea. Fisheries Oceanography, 1: 180-188.

Zar, J. H. 1984. Biostatistical Analysis. Prentice-Hall, Inc., New Jersey. 718 pp. 